\title{
ORDER ACQUIRING AND PROCESSING IN THE VIRTUAL FACTORY
}

\author{
Adrian Plüss and Charles Huber \\ Centre of Process Design [ZPA], \\ University of Applied Science, 5210 Windisch, SWITZERLAND \\ a.pluess@fh-aargau.ch; ch.huber@fh-aargau.ch
}

\begin{abstract}
Setting up virtual organizations such as the virtual factory are a new way of doing business where companies can successfully cooperate to address new markets they will never be able to address alone. This paper presents the order acquiring and-processing done by $a$ web-based intranet platform. Through intranet communication, all partner companies can post projects and seek possible cooperation partners. From the internet portal a customer can place a demand to the virtual factory, which is then transmitted trough an internal order management system to all partners. In a next step all partner can see the demand or can try to satisfy the order. The paper shows that in a virtual organization, roles and rules are very important issues besides ICT. The paper also presents how the net2net communication between three other virtual factories in Switzerland and Germany are built using the same concept.
\end{abstract}

\section{INTRODUCTION}

Co-operation is not new to industry, but in the past, companies were operating in a business environment of relatively stable markets (Schuh $\mathrm{G}$ et al., 1998). In recent time the economic pressure increased considerably and forced companies to establish cooperative structures. At the same time customers demand more complex products, enhanced services and the achievement of perfect logistic quality (Wiendahl, H.P. et al., 2002). The virtual factory (VF) in question in the northwestern part of Switzerland is linking together of real companies for the purpose of entering new markets or realizing concrete projects that for the individual companies would not be possible in a profitable manner (Collins Ph. et al., 2003; Huber, Ch., 2001; Katzy, B. et al., 1996; Schuh G. et al., 1996). Today, it is increasingly clear that co-operation in networks, the selection of appropriate partners, and the efficient use of information technology in order to optimise inter-company communication represent important competitive advantages. As the cooperative association offers a broad spectrum of products and services, it is more attractive than the individual SME (Plüss, A. et al., 2002; Plüss A., 2002). With an order orientation, the core competencies of the network partners are utilized efficiently and flexibly. At present, there are 37 companies in the network, employing a total of 3'000 employees. Their core competencies lie in the areas of engineering and services, mechanical 
processing, precision mechanics, sheet metal processing, metal working, surface treatments, heat treatments, fitting, welding techniques, plastics injection molding, plastics working, electrical and electronic engineering. In the entire value chain, the VF offers total solutions and services for assemblies and sophisticated components and replacement parts (Plüss. A., 2002).

\section{DESCRIPTION OT THE NETWORK SOLUTION}

\subsection{General}

Figure 1 describes 4 different network levels of VF: from the company to the network, inside the network, between the networks and the network level to the customer. With level 1 the partners are communicating to the market using individual company websites. Inside the network different processes are supported such as order acquiring, order processing, knowledge management, training of the partner and acquiring of new partners. Level 2 presents the four different networks in one international portal called www.virtuelle-fabrik.com. Form this international portal, four different national networks, two in Germany and two in Switzerland, are reached. Level 3 shows the interface from each partner communicating with the VF. Level 4 describes the interface to the market, where all the services and competencies of the partners are shown and where the customer can interact with the VF by the buttom demands.

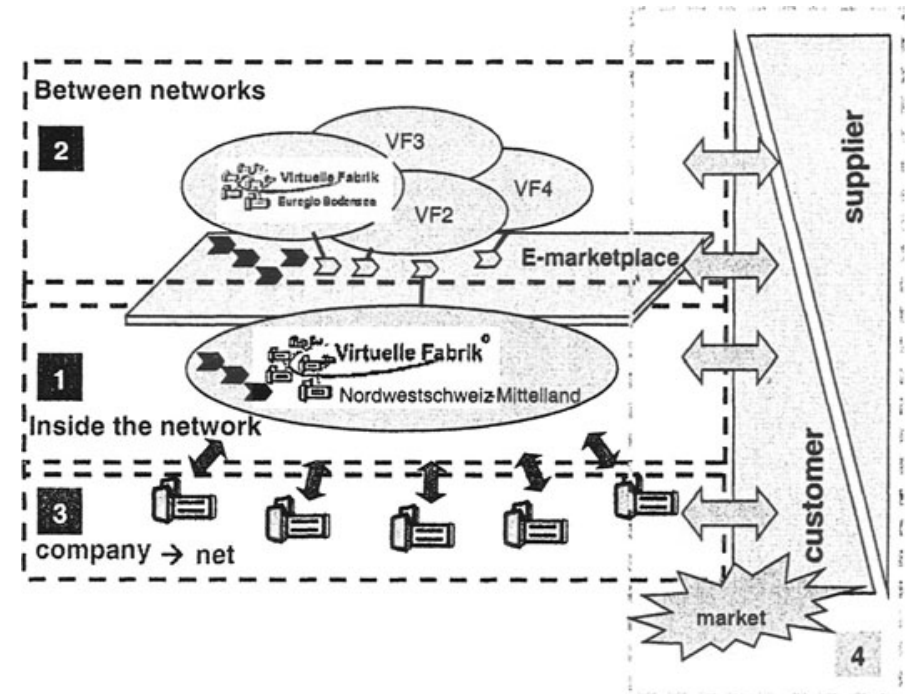

Figure 1 - The four different levels working within the VF. 
An Intranet platform was set up to facilitate communication within the VF (see Figure 2). Through Intranet communication, all partner companies can post projects and seek possible cooperation partners. One of the ground rules of the VF is that the partner companies must check the Intranet platform at least once a day. This obligation was agreed upon so that projects can be processed as rapidly and efficiently as possible.

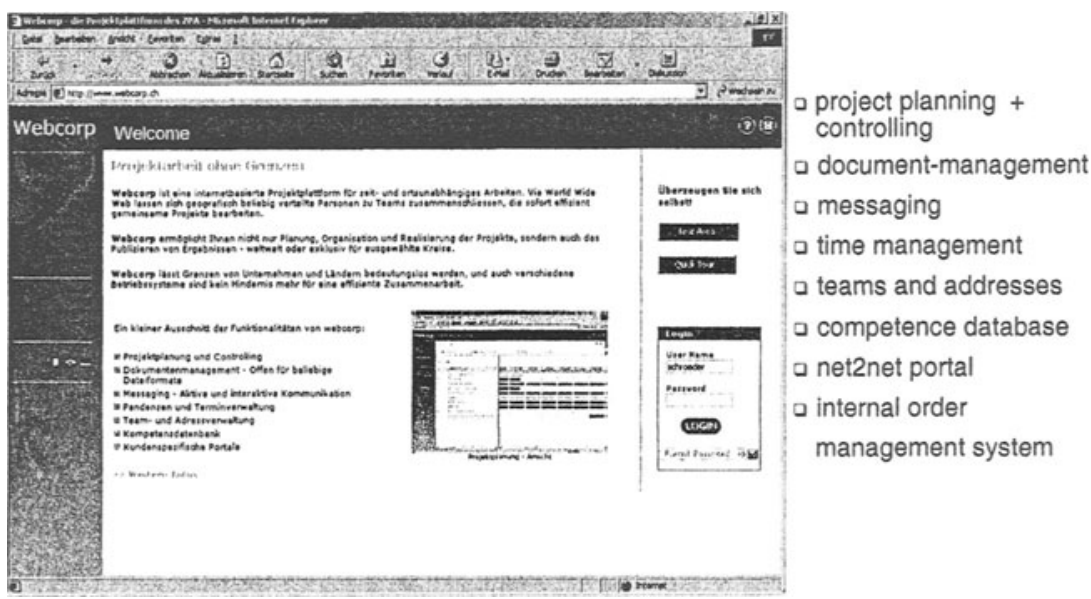

Figure 2 - Web-based intranet platform "Webcorp" to facilitate communication within the VF and the other portals

\section{ROLES AND RULES}

Within the VF the following roles or business processes can be distinguished (see Figure 3). The order broker acquires external orders for project-based partnerships within the VF. The broker also takes on the sales function and markets the competencies of the company network. The order broker is the entrepreneurial motivating force behind the formation of one or more concrete partnerships within the VF. The order broker can be an external broker under contract to the VF to sell goods and services for the VF, or any one of the partner companies in the VF can act as a broker.

The order manager brings together the resources and competencies of the partner companies within the VF, signs for order processing, and is responsible for project management. During the course of the project lead time, the order manager is the contact person for the customer. He signs the sales contract with the customer and supply contracts with VF-internal partners and external suppliers. 


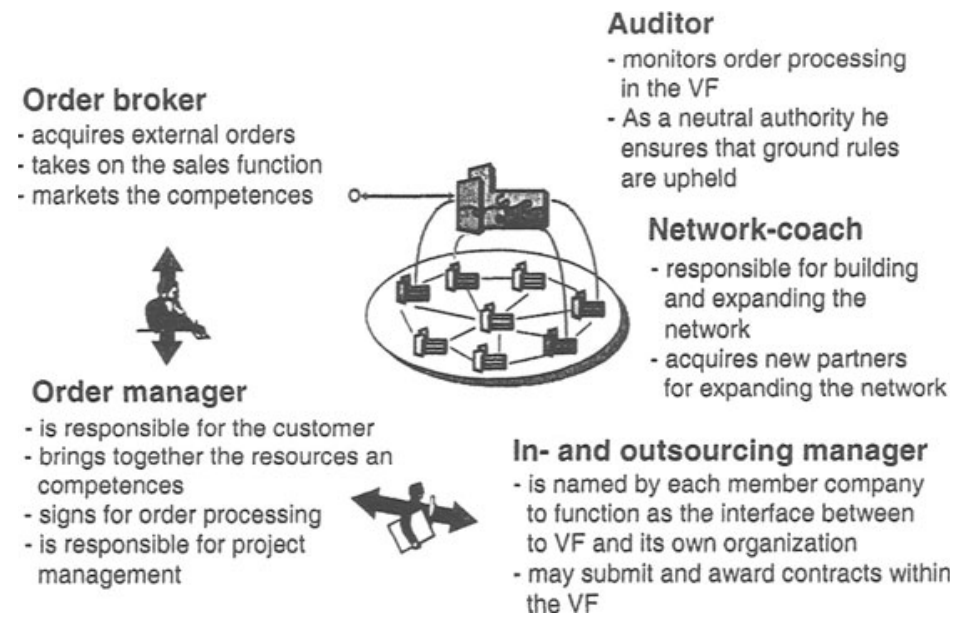

Figure 3 - Roles and Rules within the Virtual Factory (VF)

The in- and outsourcing manager is named by each member company to function as the interface between the VF and its own organization. This in- and outsourcing manager may submit and award contracts within the VF.

The network coach is responsible for building and expanding the network. One of his most important tasks is relationship management among the network partners. $\mathrm{He}$ is also responsible acquiring new partners.

The auditor monitors order processing in the VF as a neutral authority and ensures that the ground rules are upheld.

\section{INTERNAL ORDER MANAGEMENT SYSTEM IOMS}

The Internal Order Management System (IOMS) is a tool developed by the centre of process design, where a customer demand is systematically handled through different process steps such as demands, offers to orders (Huber, Ch. et al., 2002).

\subsection{Demands}

There are two different possibilities to put demands: externally by a customer using the World Wide Web or internally by the network broker. If there is a demand posted on the web, every partner receives an email message. Going into the intranet a list shows the actual demand posted in the VF. The first partner in touch (broker) can now put in additional information and documents. A partner can now show interest in this demand and can see any further development with a newsletter. Every 
partner must visit the demand box a least once a day. The first partner in touch (broker) now moves the demand into the next box called offers. If an external demand is posted using the web interface a broker has to be found within 24 ours. If no one takes the external demand within 24 ours, a so called cleaner (only in charge of the network for a certain time) is temporarily in charge to find actively the broker.

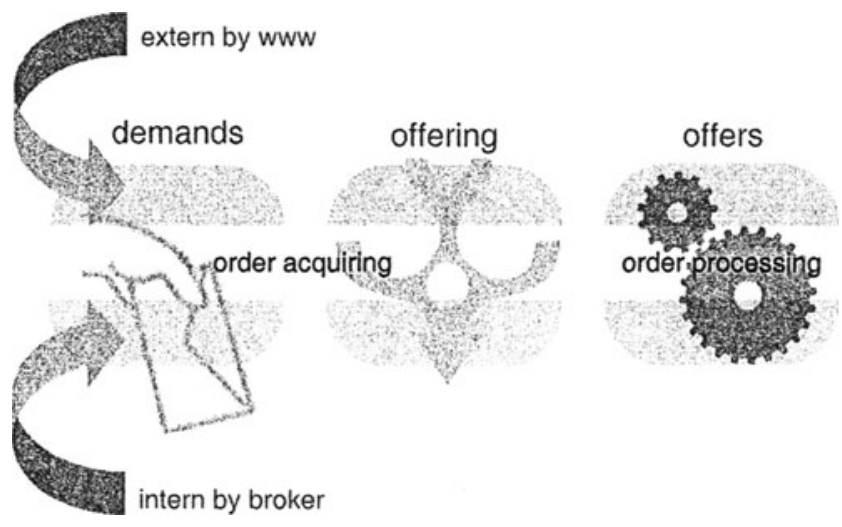

Figure 4 - Concept of Order acquiring and -processing in the VF

\subsection{Offers}

If the demand is taken into the offering box, the broker gets in contact with the customer to get some additional information concerning the customer demand. Every customer contact is noted and additional documents are posted into the web so that all partners have the same information level. Now every interested partner is asked to make an offer. At this stage the order manager, who is the responsible person for the customer gets in charge. If there is a partner found for the customer demand the demand is posted by the order manager into the international portal VF2VF where the procedure is repeated. It is important to know that each network acts independently, so the partners form the North-western part of Switzerland are not able to see into the IOMS form the eastern part of Switzerland. Only by choosing the portal VF2VF they are able to interact with each other. 


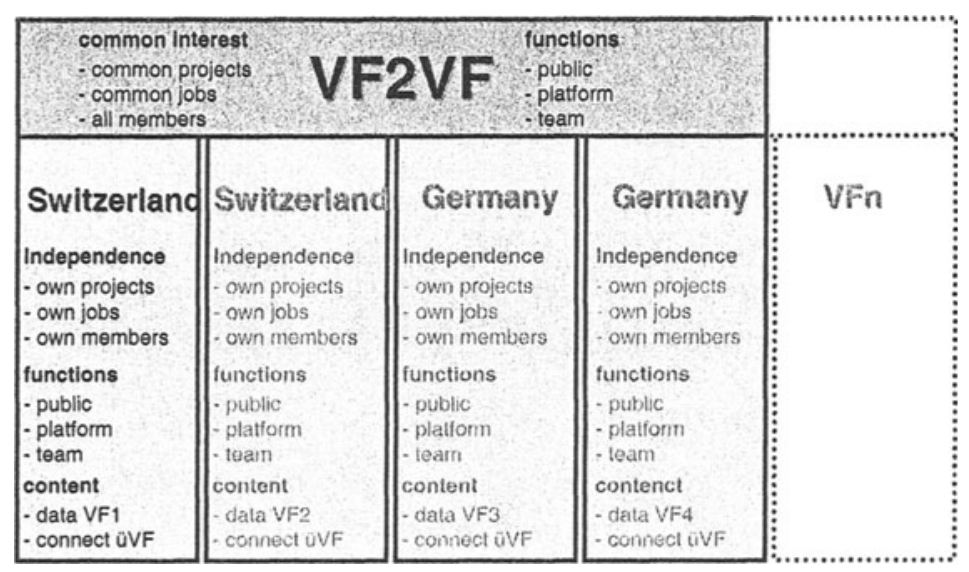

Figure 5 - Linking-up the four networks built of by the same concept

\subsection{Orders}

The order manager is in charge to notice every status change in contact with the customer. The partners are informed by automatically generated mails. The partners use therefore a project room, where only the partners for this specific order are involved and no more all the partners of the VF (Leimstoll, U. et al., 2002). Ending the order the order manager informs all the partners about the success of the order acquiring and order processing. The status of an finished project is also put into the IOMS as information

\section{CONCLUSIONS}

The VF is a network of 37 companies that make available their core competencies for the production of joint orders. The volume of the orders realized in a short period of time and the number of customer inquiries received confirm that there is a market demand for virtual companies. With their core competencies the partner companies are leaders in their branches. Together, they have mutual know-how at their disposal, and they form a stable platform. This, as well as their joint market processing, is what distinguishes them from traditional work alliances, consortia, or general contractors. The enterprise culture of the partner companies is based on openness, readiness to share information, trust, and honesty. Personal contact among representatives of the partner companies has proved to be indispensable. SMEs are predestined to become partners, for owners and general managers often become actively involved. This results in rapid decision-making.

The newly developed intranet toolset has now - beside a competence database and net2net portal - a new internal order management system, where the order acquiring 
and order processing can be followed at every stage by the partners. For example, the demand which is placed in by the World Wide Web, the broker or a partner can be followed from the demand to the offering and to the order. Of course every partner can take care of the demand depending on his competencies. There is a good instrument to guarantee the transparency on the platform (Plüss A., 2002). Furthermore projects can be done directly in the platform Webcorp.

Up to now, the VF has executed mainly co-operative production projects in which individual partner companies handle design and development. The idea that the VF might sell systems, however, has led to the vision of VF partners working on development together, so that the customer can come with just one set of specifications, have the goods and services configured, and finally receive the product.

\section{ACKNOWLEDGEMENTS}

The authors would like to thank all the companies involved in the Virtual Factory.

\begin{tabular}{|c|c|}
\hline Saln & address \\
\hline 3M (Schweiz) AG www. 3 m.com $/ \mathrm{ch}$ & Eggstrasse 93, 8803 Ruschlikon \\
\hline Aebi Industrievertretung & Hauptstrasse 18,2560 Nidau BE \\
\hline $\begin{array}{l}\text { Ascom Manufacturing AG, Automation } \\
\text { www.ascom.ch/elektronik - }\end{array}$ & Freiburgstrasse 251, 3018 Bern \\
\hline $\begin{array}{l}\text { Ascom Manufacturing AG } \\
\text { Mechatronic www.swissmanufacturing.ch }\end{array}$ & Freiburgstrasse 251,3018 Bern \\
\hline Aubry AG www.aubryag.ch & Ringstr. 4, 5432 Neuenhof \\
\hline Bichsel Consulting www.bichselconsulting.ch & Alpenweg 27, 3150 Schwarzenburg \\
\hline Bruco AG www.bruco.ch & Riedgrabenstrasse 16, 8153 Rumlang \\
\hline CELLPACK AG www.cellpack.com & Anglikerstrasse 99,5612 Villmergen \\
\hline Debrunner AG Wettingen www.debrunner.ch/wettingen & Seminarstr. 92, 5430 Wettingen \\
\hline ELMOTEC Antriebstechnik AG www.elmotec.ch & Gewerbestrasse 30, 5314 Kleindöttingen \\
\hline Eugen Seitz AG www.seitz.ch & Spitalstrasse 204,8623 Wetzikon \\
\hline Fernand Hofer GmbH Marktauftritt www.FernandHofer.ch & Häsiweg 25,5018 Erlinsbach \\
\hline Gebr. Bräm AG www.gebrbraem.ch & Lerzenstrasse 4, 8953 Dietikon \\
\hline IFTEST AG www.iftest.ch & Schwimbadstrasse 43,5430 Wettingen \\
\hline Innowateam AG www.virtuelle-fabrik.ch & Flugplatzstrasse 5, 8404 Winterthur \\
\hline Jehle AG www.jehleag.ch & Büntenstrasse 180,5275 Etzgen \\
\hline KUBO-TECH AG www.kubotech.ch & Im Langhag 5, 8307 Effretikon \\
\hline Lancom AG www.lancom.ch & Riedstrasse 1, 8953 Dietikon \\
\hline Maag Technic AG www.maagtechnic.ch & Sonnentalstr. 8, 8600 Dübendorf \\
\hline Mauell AG www.mauell.ch & Furtbachstrasse 17, 8107 Buchs \\
\hline Meier + Co. AG www.meico.ch & Oltnerstrasse 92,5013 Niedergösgen \\
\hline $\begin{array}{l}\text { Metallveredlung Kopp AG www.kopp-metallveredlung.ch } \\
\text { nanoTRONIC GmbH www.nanotronic.ch }\end{array}$ & $\begin{array}{l}\text { Tägerhardstrasse } 94,5430 \text { Wettingen } \\
\text { Dreihubelweg } 79,3250 \text { Lyss }\end{array}$ \\
\hline Partech AG www.partech.ch & Pilatusstrasse 4, 6036 Dierikon \\
\hline
\end{tabular}


Name of the company

Referenz Gmbh www.referenz.ch

Rihs Maschinenbau AG www.virtuelle-fabrik.ch

Romay AG www.romay.ch

Sarna Plastec AG www.sarna-plastec.com

Sika Schweiz AG Tunneling \& Mining www.sikastm.com

Styner+Bienz FormTech AG www.styner-bienz.com

Suter \& Bähler Installationen AG www.sbinstal.ch

Suter Maschinenfabrik AG www.suter-estech.ch

Wyser AG www.wyserag.ch

Zemp+Partner Design www.zempdesign.ch

ZPA - Zentrum für Prozessgestaltung Aargau www.zpaargau.ch

\section{address}

Kirchbachstr. 6a, 8600 Dubendorf

Bielstrasse 29, 2542 Pieterlen

Gontenschwilerstr. 5, 5727 Oberkulm

Industriestr. 34, 6060 Sarnen

Bellikonerstrasse 218, 8967 Widen

Freiburgstrasse 556, 3172 Niederwangen

Räffelstrasse 29, 8045 Zürich

Aabachstrasse 22, 5703 Seon

Gartenstrasse 23, 5012 Schönenwerd

Technoparkstrasse, 8005 Zurich

Steinackerstr. 5, 5210 Windisch

Figure 6 - Partners of the Virtual Factory in Switzerland

\section{REFERENCES}

1. Collins, Ph.; Pluss, A. und Huber, Ch.: Communities of practice - the virtual factory (2003): www.virtual-organization.net (in preparation)

2. Huber, Ch. (2001): Frischer Wind im Beschaffungsmarkt; Kommunikation Nr. 10; 2001

3. Wiendahl, H.P. and Lutz, S. (2002): Production in networks, Annals of the CIRP Vol 51, p. 1- 13.

4. Huber, Ch., Plüss, A. und Schoch, R. (2002): Auftragsmanagement im virtuellen Netzwerk, new management Nr. 12, p.63-69, 2002

5. Katzy, B.; Schuh G, und Millarg K. (1996): Die virtuelle Fabrik - Produzieren im Netzwerk - neue Märkte erschliessen durch dynamische Netzwerke, in Technische Rundschau 43/1996, p 30-34

6. Leimstoll, U. und Wackernagel, T. (2002): Internet-Plattform fur eine Learning Community im Projektmanagement (3. Erfahrungsbericht), Basel: Fachhochschule beider Basel (FHBB), Institut für angewandte Betriebsökonomie (IAB), Arbeitsbericht E-Business Nr. 9, 2002

7. Pluss, A. und Huber, Ch. (2002): Virtual Organizations - State of the art and development of the Virtual Factory, Proceedings of the $2^{\text {nd }}$ Nat. Meeting of IPLnet, 10/11th of Sept. 2002, Saas Fee Switzerland. www.iplnet.ch

8. Pluss, A. (2002): The concept of the virtual Company Northwest and Central Switzerland - a new network cooperation. Proceedings of the Strategic Direction Group Workshop, 22/23rd of April 2002, Nottingham and Bristol

9. Pluss, A. (2002): Virtual Factory Northwest and Central Switzerland - practical experience of a virtual organization. $8^{\text {th }}$ International Conference on Concurrent Enterprising; Virtual Professional Networking, Communities of Practice, 17-19 June, Rom

10. Pluss, A.: Wissensidentifikation und -darstellung; aus Luthy, et al. (2002): WissensmanagementPraxis, vdf-Verlag 2002, p. $85-96$

11. Schuh G; Millarg K. und Göransson A, (1998): Virtuelle Fabrik, neue Marktchancen durch dynamische Netzwerke, Carl Huber Verlag, Munich, 1998 